\title{
Developing Cold-tolerant Fruit Cultivars for Finland
}

\author{
Heimo Hiirsalmi and Jaakko Säkö \\ Agricultural Research Centre, Institute of Horticulture, SF-21500 Piikkiö, Finland
}

Despite the extreme northern position of Finland between the 60th and 70th parallel of latitude, it is feasible to carry on economically profitable fruit growing. This is made possible by the warm Gulf Stream current. As it skirts the shores of northern Europe, the Gulf Stream creates an exceptionally favorable climate in the Nordic countries. How well perennial plants do at the extreme limits of their natural cultivation areas is influenced particularly by the length of the growing season (days with mean temperatures at least $+5 \mathrm{C}$ ), the sum total of the effective temperature (the positive difference between the mean temperature of the growing season and $+5 \mathrm{C}$ multiplied by the length of the growing season), the rigor of the winter, and the thickness of the snow cover, among other factors. The length of the growing season in southwestern Finland, where the Inst. of Horticulture, Agricultural Research Centre, is located, is > 173 days and in northern-most Lapland under 124 days. The respective cumulative effective temperatures for these regions are $>1295$ and under 710

Severely cold winters, when the temperature in southern Finland may drop below $-30 \mathrm{C}$ and in Lapland close to $-50 \mathrm{C}$, occur, on average, once in 10 years. Under these conditions, the parts of woody perennial plants that are without snow cover are damaged. Injury to the root system is also likely if the snow cover during severe cold periods is thin. Exceptionally hard winters for perennial plants have occurred in Finland in 1955-56, 1965-66, and 198485 (Sake, 1957b; Sako and Pessala, 1967; Sako and Yli-Pietila, 1987). The coldest winter of this century was Winter 1986-87 (Sako and Lundén, 1988).

Most fruit tree and berry plant species and cultivars have been developed in consideration of different, generally more temperate conditions than those normally prevailing in Finland. Hence, the hard winters of Finland cause great losses among the material imported from abroad. Thus, the cultivation of fruit trees and berries in Finland cannot be developed solely with the aid of foreign genetic material-we must breed domestic, winter-hardy cultivars suited for Nordic climatic conditions. Good winter hardiness is among the more crucial challenges facing plant breeders in Finland.

Commercial tree fruit production in Finland is focused almost exclusively on the apple, grown mainly in the southwestern part of the country, although home and hobby apple-growing occur as far north as central Finland. Plums and sour cherries are produced to a limited extent, especially in the southwestern archipelago. Sweet cherry growth does not succeed in Finland, and the pear has remained an item for a few hobbyists. The most important berry plants in Finland are the strawberry and the blackcurrant. The black cur- rant does well as far north as the Arctic Circle, when suitable cultivars are chosen. The northern limit for acceptable production of strawberry, red and white currant, gooseberry, and raspberry is north-central Finland. For successful overwintering, the most advantageous growing sites for raspberry are found in snowy eastern Finland on the slopes of tree-covered hills. With some meager success, attempts have been made to adapt berry plant species of foreign origin, such as the American highbush blueberry, lowbush blueberry, and cranberry, to Finnish conditions. Some efforts to develop new plants through interspecific breeding have been made. The potential for cultivation of the lingonberry and the sea-buckthorn has also been explored.

\section{GENERAL OBJECTIVES}

Fruit breeding in Finland has been centered in the Inst. of Horticulture at Piikkiö. For fruit trees, breeding efforts currently are focused solely on the apple in an attempt to develop hardy rootstock, as well as hardy and good-quality cultivars. Hardy strains of plum, sour cherry, and apple have been collected for the gene bank with a view to further breeding. The most important breeding targets among the berry plants have been the black currant, strawberry, raspberry, nectar raspberry, arctic bramble, highbush blueberry, and sea-buckthorn. Of these, the bush berries, as well as the raspberry and nectar raspberry, have required breeding for intensified winter hardiness.

Three different breeding methods have been used at the institute: crosses between different cultivars of the same species, interspecific crosses (possibly connected with doubling chromosome numbers), and the forming of pure lines through repeated self-pollinations with cultivars (linked with combination crossing). The first two methods have been very useful, but repeated self-pollinations have most often produced progenies weakened to such an extent that winter loses have been heavy.

\section{BREEDING OF SPECIFIC FRUIT CROPS}

\section{Apple (Malus domestics Borkh.)}

Cultivars. During the past decades, hundreds of foreign apple cultivars have been tested at the institute. The aim has been to find cultivars that are as winter-hardy as possible, that produce goodquality fruit, and that are suited for a cool, short growing season. Several cultivars being tested come from eastern Canada, where they perform at least satisfactorily. Yet only a few of them are suitable for cultivation in the more coastal climate of Finland. 
Table 1. The new Finnish apple cultivars.

\begin{tabular}{llc}
\hline \hline Cultivar & \multicolumn{1}{c}{ Cros s } & $\begin{array}{c}\text { Released } \\
\text { cultivation }\end{array}$ \\
\hline Pirja & Huvitus $\times$ Melba & 1981 \\
Maikki & Melba $\times$ Huvitus & 1981 \\
Samo & Melba $\times$ Huvitus & 1982 \\
Make & Atlas $\times$ Yellow Autumn Kallvill & 1981 \\
Jaspi & Lobo $\times$ Huvitus & 1981 \\
\hline
\end{tabular}

Table 2. The new Finnish small-fruit cultivars.

\begin{tabular}{|c|c|c|}
\hline $\begin{array}{l}\text { Species and } \\
\text { cultivar }\end{array}$ & Cross & $\begin{array}{c}\text { Released } \\
\text { for cultivation }\end{array}$ \\
\hline \multicolumn{3}{|l|}{ Strawberry } \\
\hline Hiku & Senga Sengana $\times$ Redgauntlet & 1984 \\
\hline Mari & Pocahontas $\times$ Lihama & 1988 \\
\hline \multicolumn{3}{|c|}{ Wood strawberry } \\
\hline Minja & $\begin{array}{l}\text { Fragaria vesca } \times \text { Fragaria vesca var. } \\
\text { semperflorens }\end{array}$ & 1986 \\
\hline \multicolumn{3}{|c|}{ Green currant } \\
\hline Vertti & Öjebyn self-pollination & 1987 \\
\hline \multicolumn{3}{|l|}{ Raspberry } \\
\hline Ville & Ottawa $x$ wild raspberry strain & 1986 \\
\hline \multicolumn{3}{|c|}{ Nectar raspberry } \\
\hline Heija & Malling Promise $\times$ Selection Merva & 1975 \\
\hline Heisa & Malling Promise $\times$ Selection Merva & 1981 \\
\hline \multicolumn{3}{|c|}{ Arctic bramble } \\
\hline Mesma & Wild arctic bramble strain & 1972 \\
\hline Mespi & Wild arctic bramble strain & 1972 \\
\hline Pima & Mespi x Mesma & 1982 \\
\hline Aura & Alaska bramble $x$ arctic bramble & 1986 \\
\hline Astra & Alaska bramble $x$ arctic bramble & 1986 \\
\hline \multicolumn{3}{|c|}{ Highbush blueberry } \\
\hline Aron & Rancocas $\times$ (bog blueberry $\times$ Rancocas) & 1982 \\
\hline
\end{tabular}

Apple cultivars for commercial production have remained nearly the same for more than 30 years. Considerable changes have occurred in the percentages of the various cultivars grown. The cultivation of 'Wealthy' declined after the hard Winter 1955-56. The same decline occurred with 'Åkero' after Winter 1965-66. Canadian 'Lobo' became the principal cultivar 30 years ago and it has maintained this position, averaging $\approx 45 \%$ of annual apple production. Newer cultivars are Canadian 'Atlas' and 'Raike'. Other cultivars in commercial production include 'Transparence Blanche', 'Melba', and 'Kanel'.

The breeding program launched at the institute in 1958 has, most importantly, the aim to develop high-yield and high-quality cultivars adaptable to Finland's climate. From 1958 to 1966, 30 crosses were made, in which 17 cultivars were used. With winter hardiness and productivity in mind, the cultivars Antonovka, Atlas, Huvitus, and Kanel were chosen" as parents. To improve quality, as well as productivity, cultivars such as 'Melba', 'Lobo', 'Gyllenkrok Astrakan', 'Yellow Autumn Kalvill', etc., were used. The cross progeny, comprising a total of $\approx 10,800$ individuals, have, as a whole, been hardy. Despite the hard winters before the selection, only $7 \%$ of the trees perished. All told, 224 selections have been included in further evaluation. Nearly all have proven to be very winter-hardy; injuries were minor even in the record-breaking cold of Winter 1986-87.

To date, the crossing program has produced five apple cultivars (Sake, 1982; Sako and Laurinen, 1985). Under the conditions prevailing in southern Finland, all are either summer or autumn cultivars. In order of earliness of maturity, they are: 'Pirja', 'Maikki' and 'Same', 'Make', and 'Jaspi' (Table 1). Of the additional selections, some maturing later than those named above, there are still at least 10 valuable enough to be named and adopted for cultivation.

Rootstock. The rootstock plays a major role in determining winter hardiness of apple trees, having both direct and indirect effects on the tree. The direct effect is manifested in the inherent hardiness of the rootstock when the soil is deep-frozen. The indirect effect is apparent in the reaction of the grafted scion cultivar, how early defoliation takes place, and how early the shoots go into dormancy.

The commonly used Mailing rootstock M. 1, M.2, M.4, M.9, and M.26 have not proven sufficiently hardy for Finland (Meurman, 1943, 1947; Sake, 1958). Some seedling rootstock of hardy cultivars, such as 'Antonovka' and 'Sugar Miron', have proven hardier under winter conditions than the Mailing types (Sake, 1975). Furthermore, trees grown on seedling rootstock have not shown more individual variation in growth and cropping than trees propagated on clonal rootstock (Sake, 1953, 1957a). Today, however, seedling rootstock are used infrequently for apples.

The Swedish clonal rootstock 'A2' has been, until recently, the most commonly used one in Finland. Now, however, the domestic clonal rootstock 'YP', developed at the institute, is replacing it. The 'YP' originates from the seed of an open-pollinated Siberian crabapple tree [Malus baccata (L.) Borkh] (Sake, 1977). In our comparative trials, its winter hardiness has been found to be better than that of any other rootstock. A grower response questionnaire dealing with the damage to orchards caused by the severely cold Winters 1984-85 and 1986-87 has confirmed the favorable impression of the 'YP' rootstock among producers (Sako and Lundén, 1988; Sako and Yli-Pietilä, 1987).

On the basis of the results obtained in the field and in laboratory tests, the hardiness of rootstock under Finnish conditions has been assessed as follows (Sake, 1984): very hardy, 'YP'; hardy, 'Antonovka' seedling; moderately hardy, 'A2'; not acceptably hardy, M.7, MM.111, and M.2; susceptible to frost injury, 'Bittenfelder' seedling, 'Grahams Jubiläum' seedling, 'Normandie' seedling, M.4, M1, MM.103, MM.110, MM.109, MM.106, M.9, and M.25; very susceptible to frost injury, MM.104, MM.101, MM.112, MM.105, MM.113, and MM.102.

'YP' is a very promising rootstock where winter hardiness is an important requirement for apple cultivation. It is a very vigorous rootstock producing sturdy trees. 'YP' has been crossed with the dwarf rootstock M.26 and the semi-dwarf rootstock M.27, which are not suited for our climate. The aim is to produce a winter-hardy dwarfing rootstock.

\section{Strawberry (Fragaria $\times$ annanasa Duch.)}

With the strawberry, it is possible to find cultivars developed for mild climates that can be grown in Finland. The best results have been obtained with German 'Senga Sengana' and Danish 'Zefyr', which have become the most common cultivars in Finland (Säkö et al., 1979).

Due to the protection offered by the snow, strawberry most often winters well. This being the case, good winter hardiness, vigor, and other characteristics have been major considerations when making selections for comparative trials.

In 1984, the first Finnish strawberry cultivar, developed as the result of the breeding program, was released for cultivation under the name 'Hiku' (Hiirsalmi and Sake, 1985). This cultivar, resulting from the cross 'Senga Sengana' $\times$ Scottish 'Redgauntlet', has proven to be the best yielding, the most vigorous, and the most winterhardy of the cultivars tested and grown in Finland. In 1988, a cross between American 'Pocahontas' and German 'Lihama' was released for cultivation under the name 'Mari'. 'Mari' is an early ripening cultivar with winter hardiness. In 1986, the vigorous and hardy wood strawberry 'Minja', which produces small aromatic berries and is meant for home growing, was named and released (Hiirsalmi et al., 1987).

\section{Black currant (Ribes nigrum L.)}

Black currant cultivars commonly grown in Central Europe and Great Britain do not do well under Nordic climatic conditions. The most important of the cultivars grown in Finland are local strains from northern Sweden and Finland (Hiirsalmi, 1982). Their favorable characteristics, such as their winter hardiness, and the favorable characteristics of the central European and British cultivars have been used in cross-breeding attempts to combine these characteristics. The Swedish 'Ojebyn', which at present is the most common cultivar in Finland, has been used in many crosses. In addition to 
being very winter-hardy, it is also field-resistant to gooseberry mildew, which badly infects most cultivars.

The best selections have been obtained by crossing the 'Öjebyn' with the British 'Wellington XXX' cultivar. Upright growth of the latter is well suited for mechanical harvesting; however, it is susceptible to winter injury and mildew infection. The most promising selection, 67008081, will be proposed for naming and release. It is a good cropper, has upright growth, is field-resistant to gooseberry mildew, and, in addition, is winter-hardy.

Plants of self-pollinated 'Ojebyn' black currant progeny with green berries can be found regularly (Junnila and Hiirsalmi, 1987). In these berries, the amount of anthocyanin pigments is very low or the pigments are missing altogether. A black currant cultivar with green berries was released in 1986 by the Inst. of Horticulture under the name 'Vertti' (Junnila et al., 1987). Its resistance to gooseberry mildew and its winter hardiness have been found to be good, while the crop level approximates that of the parent cultivar. When ripe, the flavor of the yellow-green berries is typical of the black currant, but milder and less acid.

\section{Highbush blueberry (Vaccinium corymbosum L.)}

Cultivation of the American highbush blueberry, using cultivars developed in the United States or Central Europe, has not succeeded under Nordic climatic conditions (Hiirsalmi, 1988; Hiirsalmi and Sake, 1973). The main drawbacks with all cultivars have been their rather low winter hardiness and susceptibility to blueberry canker, the commonly encountered stem disease caused by the fungus $\mathrm{Fu}$ sicoccum putrefaciens Shear.

To create highbush blueberry selections better-suited to Nordic climatic conditions that are disease-resistant and at the same time give good fruit quality and yield, the institute has tried crossing domestic Vaccinium species with the highbush blueberry (Hiirsalmi, 1973, 1977a, 1977b; Rousi, 1963). Of the northern European species, it has been possible to cross the bog blueberry ( $V$. uliginosum L.) with the highbush blueberry. Selected individuals from the progeny of crosses have been back-crossed with the highbush blueberry to improve cultural characteristics.

Selections made from the back-cross progeny have a shorter growth habit and are generally more winter-hardy and canker-resistant than the foreign cultivars. Regarding crop standard and berry size, most of the selections are in the same class with the highbush blueberry cultivars. A selection from the back-cross 'Rancocas' $\times$ (V. uliginosum $\times$ 'Rancocas') was released in 1982 under the name 'Aron' (Hiirsalmi and Lehmushovi, 1982). It has tolerated the most disastrous winters considerably better than the best American cultivars Rancocas and June in the trials at the institute. In addition, it is, to a satisfactory degree, resistant to blueberry canker and provides moderate fruit yields.

\section{Raspberry (Rubus idaeus L.)}

To some extent, the raspberry has been a part of the breeding program at the institute since 1973. At present, there are no cultivars available that are well adapted to our climatic conditions and that are also good croppers (Säkö and Hiirsalmi, 1980). In 1981, an extensive breeding project was started to develop new cultivars using, among other traits, the gene pools of the wild raspberry to combine heavy yields, winter hardiness, and disease resistance. The Canadian 'Ottawa' and 'Muskoka', the most successful commercial cultivars in Finland, have been crossed with domestic wild raspberry strains. Several promising individuals have been found among the progenies. It is, however, regrettable that they seem to have inherited small berry size in addition to the favorable characteristics of the wild raspberry-the winter hardiness and fine aroma of the berries. In 1988, the first of these very winter-hardy selections was put on the market under the name 'Vine'. It is a cross between the cultivar Ottawa and a Finnish wild raspberry strain.

\section{Nectar raspberry (Rubus idaeus $\mathbf{L} . \times$ Rubus arcticus L.)}

The aim in breeding the nectar raspberry, ongoing since 1939 , has been to combine the fine aroma of the arctic bramble berries with the cultural qualities of the raspberry. The arctic bramble is, in itself, an important target for breeding at the institute. Being a native wild plant, with above-ground shoot parts that wither away before the advent of winter, winter hardiness has not been a problem.

As a result of numerous crosses and backcrosses, 'Heija', the first nectar raspberry cultivar, was released in 1975 (Hiirsalmi and Säkö, 1976). However, it inherited some of the unfavorable characteristics of the raspberry, especially poor winter hardiness. Since then, the sister selection of 'Heija' has proven to be of greater promise. It was released under the name 'Heisa' in 1981 (Hiirsalmi and Sake, 1981). This cultivar, which resembles the raspberry in its growth characteristics, is superior to 'Heija' in growth habit and winter hardiness, as well as yield and berry size.

Breeding of the nectar raspberry continues with that of the raspberry. A major objective is to develop cultivars with even greater winter hardiness.

\section{Sea-buckthorn (Hippophä̈ rhamnoides L.)}

The sea-buckthorn, a wild berry growing on the western coast of Finland, also grows well under cultivation and is winter-hardy. Picking the berries, however, is a problem with the domestic seabuckthorn strains, limiting possibilities for profitable cultivation. We use subspecies and strains of the sea-buckthorn that grow in Central Europe and Asia (Rousi,. 1965, 1971) in breeding plants with fewer thorns and ones on which the berries can be picked intact. This breeding work, based on crossings and radiation, has been carried out by the institute on a small scale since 1973. In the early 1980s, we received sea-buckthorn cultivars for trial from the USSR that had been developed for Siberian conditions. Their harvestability is considerably better than that of the Finnish wild strains. However, they did not tolerate the hard winter of 1986-87 in the coastal climate of Finland even though they may winter well in Siberia at temperatures of $-50 \mathrm{C}$. The wild strains of the Finnish sea-buckthorn have not been damaged during the most severe cold winters. Selections developed by the Institute of Horticulture have wintered quite well.

The Finnish small-fruit cultivars and their parentage are listed in Table 2 .

\section{Literature Cited}

Hiirsalmi, H. 1973. Hybrids between Vuccinium uliginosum and highbush blueberry varieties. J. Yugoslav Pomol. 7:231-236.

Hiirsalmi, H. 1977a. Culture and breeding of highbush blueberry in Finland. Acta Hort. 61:101-110.

Hiirsalmi, H. 1977b. Inheritance of characters in hybrids of Vaccinium uliginosum and highbush blueberries. Ann. Agr. Fenn. 16:7-18.

Hiirsalmi, H. 1982. Sortval och förädling av svarta vinbär i Finland. Nerd. Jordbr.forskn. 64:455-456.

Hiirsalmi, H. 1988. Research into Vaccinium cultivation in Finland. Acts Hort. 241:175-184.

Hiirsalmi, H. and A. Lehmushovi. 1982. A Finnish highbush blueberry variety 'Aron'. Ann. Agr. Fenn. 21:151-154.

Hiirsalmi, H. and J. Sake. 1973. Variety trials with the highbush blueberry in Finland. Ann. Agr. Fenn. 12: 190-199.

Hiirsalmi, H. and J. Sake. 1976. The nectar raspberry, Rubus idaeus $\times$ Rubs.s arcticus- A new cultivated plant. Ann. Agr. Fenn. 15:168-176.

Hiirsalmi, H. and J. Sake. 1981. 'Heisa'-A new nectar raspberry variety. Ann. Agr. Fenn. 20:268-272.

Hiirsalmi, H. and J. Sake. 1985. A Finnish strawberry variety 'Hiku'. Ann. Agr. Fenn. 24:179-182.

Hiirsalmi, H., S. Junnila, and J. Sake. 1987. 'Minja', a Finnish wood strawberry variety. Ann. Agr. Fenn. 26:271-274.

Junnila, S. and H. Hiirsalmi. 1987. Genetic background of green fruit colour in black currant. Ann. Agr. Fenn. 26:275-278.

Junnila, S., H. Hiirsalmi, and J. Sake. 1987. A green-fruited blackcurrant variety 'Vertti'. Ann. Agr. Fenn. 26:279-283.

Meurman, O. 1943. Omenapuiden ilmastollisesta kestävyydesta. S. Puutarhavilj. Liiton Julk. 27:1-8.

Meurman, O. 1947. Iakttagelser av skador på fruktträd förorsakade av tjälen under våren 1947. Pomol. For. Årsskr. 48:63-70.

Rousi, A. 1963. Hybridization between Vuccinium uliginosum and cultivated blueberry. Ann. Agr. Fenn. 2:12-18.

Rousi, A. 1965. Observations on the cytology and variation of European 
and Asiatic populations of Hippophä rhamnoides. Ann. Bet. Fenn. 2:118.

Rousi, A. 1971. The genus Hippophae L. A taxonomic study. Ann. Bet. Fenn. 8:177-227.

Sake, J. 1953. Siemenperusrunkojen vaikutus omenapuiden satovaihteluihin. Summary: The influence of seedling rootstock upon the cropping of the apple trees. J. Agr. Sci. Finland 25:160-170.

Säkö, J. 1957a. Av frögrundstammar förorsakade variationer hos äppelträd. Frukt i År. Sver. Pomol. For Årsskr. 58:85-98.

Sake, J. 1957b. Hedelmänviljelyä kohdanneesta tuhosta v. 1955-56. Summary: On the damage to fruit farming in Finland 1955-56. J. Agr. Sci. Finland 29:1-26.

Sake, J. 1958. Eräiden suvuttomasti ja siemenistä lisättyjen persusrunkojen vaikutuksesta omenapuiden menestymiseen Suomessa. Summary: The influence of some vegetatively raised and seedling rootstock upon apple trees in Finland. Vah. Maatal.koetoim. Julk. 165:1-90.

Sake, J. 1975. Uusia talvenkestäviä omenapuuperusrunkoja ja lajikkeita. Puutarhantutk.lait. Tiedote 6:1-10.
Sake, J. 1977. YP, a new clonal rootstock for apple. Ann. Agr. Fenn. 16:88-96.

Sake, J. 1982. New Finnish apple varieties: Pirja, Maikki, Make and Jaspi. Ann. Agr. Fenn. 21:1-7.

Sake, J. 1984. Winter hardiness problems in fruit growing in Finland. Acta Hort. 168:31-36.

Sake, J. and H. Hiirsalmi. 1980. Winterhardiness and productivity of the red raspberry in Finland. Acta Hort. 112:221-227.

Sake, J. and E. Laurinen. 1985. Apple variety Same. Arm. Agr. Fenn. $25: 1-3$.

Sake, J. and K. Lundén. 1988. Talven 1986-87 tuhot hedelmä- ja marjatarhoissa. MTTK, Tiedote 1988(14): 1-34.

Säkö, J. and T. Pessala. 1967. Talven 1965-66 aiheuttamat vauriot hedel. mätarhoissa. Summary Injuries in Finnish orchards caused by winter 1965-66. Ann. Agr. Fenn. 6:53-62.

Sake, J. and M. Yli-Pietilä. 1987. Winter injury to Finnish apple orchards in 1984-85. Ann. Agr. Fenn. 26:251-259.

Sake, J., A. Ryynänen, and E. Laurinen. 1979. Mansikan lajikekokeiden tuloksia. Puutarhantutk.lait. Tiedote 19:21-32. 